\title{
APPLICATION OF MARKETING MIX CONCEPT IN STUDENT RECRUITMENT STRATEGIES: EVIDENCE FROM UNIVERSITY OF NOVI SAD, SERBIA
}

The first subject of research in this article is the review and comparison of various theoretical approaches to marketing applied in institutions of higher education. The authors have observed the marketing as an active process by which institutions of higher education attract their users' attention to the educational services they offer. The research has sought for an answer to the question which marketing mix instrument has the greatest impact on the student decision to enroll at a particular faculty at the University of Novi Sad. The study involved 783 students at six faculties of this university. The authors used a non-standardized survey questionnaire to measure the attitudes towards 26 different marketing tools, using the five-point Likert scale. Principal components factor analysis was used to classify variables. The authors singled out seven factors relevant to the faculty choice: people, physical evidence, promotion, image, resources and extra services, location and price. The results coincided with the traditional elements of marketing mix (7P) to a greater or lesser extent, confirming the results of previously conducted studies.

Keywords: marketing mix, universities, student recruitment, faculty management.

\footnotetext{
* Vesna Rodić Lukić, PhD, Faculty of Education in Sombor, University of Novi Sad vesna.rodic@pef.uns.ac.rs

** Nemanja Lukić, MSc., Faculty of Education in Sombor, University of Novi Sad nemanja.lukic@pef.uns.ac.rs
} 


\section{Introduction}

Modern-day higher education institutions are facing new challenges. They are all required to adopt the Bologna system of studies, which represents a fundamental change in comparison to the traditional system of studies, and furthermore, changes the relations between the students and the teaching staff. In addition to that, the emerging of private faculties and the introduction of accreditation system in order to establish a system of quality has caused the need for marketing activities among faculties and universities. Marketing in higher education institutions should be viewed as an active process, through which these institutions respond to the needs of the present environment, or use various channels in order to attract their users' attention to the educational service they offer, the way this service is distributed, as well as the price of the service. In such pursuit, higher education institutions should utilize marketing mix instruments, and the faculty management is expected to promote this approach to operation.

The main research point of this study is to find out factors that determine students' choice of a faculty within a given university that will determine which specific marketing mix instruments to apply. A particular faculty may have suitable resources but it has to meet one's personal and professional needs as well. A student will choose a faculty with an appropriate program in accordance with his studying orientation. The proposition of this paper is that the marketing mix instruments applied at a faculty should be optimized in a way that they will attract more students to study there.

The marketing mix is one of the major concepts (or constants) in marketing, and there is practically a universal agreement in the scientific literature that the most important marketing mix instruments(Rodić \& Lukić, 2012; ${ }^{1}$ Vasiljev, $2005^{2}$ )are: product, price, place (sales and distribution) and promotion. The marketing mix is often referred to as the " $4 \mathrm{P}$ " strategy in English literature, and this abbreviation originates from the initial letters of the English words for the mentioned four instruments (Product, Price, Place and Promotion). Each of the marketing mix instruments represents a variable that is manipulated with, in order to attain the set objectives. Practice has shown that a combination of instruments gives better results than relying on a single instrument, especially within a long-term strategy (Vasiljev, 20053). When it comes to application of the marketing mix for services, the experience has shown that this concept requires reconsideration, namely, extending the classic marketing mix. Booms and Bittner (1981) have presented a modified and extended marketing mix for services, comprising seven elements: service product, price, place/distribution, promotion, people, physical

1 Rodić, V., \&Lukić, N. (2012).Specific features of the application of the marketing mix concept in institutions of higher education. Norma, 17(2), 257-268.

$2 \quad$ Vasiljev, S. (2005): Marketing principi, Novi Sad, Prometej, 418.

$3 \quad$ Ibid 
evidence and service process. Higher education institutions possess intrinsic features, necessitating revision of the traditional marketing mix concept so it can be efficiently applied to these institutions. A number of authors (Enache, 2011; Ivy, 2008; ${ }^{5}$ Maringe, $2006^{6}$ ) have tried to determine a specific combination of marketing mix instruments which would be appropriate for these institutions.

\section{Application of marketing in higher education}

The issue of applying marketing in higher education institutions has primarily been a subject of theoretical studies in our country, in contrast to the rest of the world, where empirical researches on this topic are not that rare. One of the subjects of this research is the review and comparison of various theoretical approaches to this interesting issue. The literature on this subject is diverse, in terms of the authors' expertise and focus. Besides theoretical reviews, there are a few research papers on the application of marketing mix in institutions of higher education. Most of the authors have examined the obtained data using factor analysis, thus determining the factors with a major influence on students' choice of faculty.

Previous studies focusing on the field of marketing in higher education institutions have been conducted by several authors worldwide (Beneke \& Human, 2010; ${ }^{7}$ Chen \& Zimitat, 2006; ${ }^{8}$ Enache, 2011 $;{ }^{9}$ Ivy, 2008; ${ }^{10}$ Kallio, $1995 ;{ }^{11}$ Khan \& Qureshi,

Enache, I.-C. (2011). Marketing higher education using the 7Ps framework. Bulletin of the TransilvaniaUniversity of Braşov, 4(1), 23-30.

5 Ivy, J. (2008). A new higher education marketing mix: the 7Ps for MBA marketing. International Journal of Educational Management, 22(4), 288-299.

6 Maringe, F. (2006). University and course choice: Implications for positioning, recruitment and marketing. International Journal of Educational Management, 20(6), 466-479.

7 Beneke, J., \& Human, G. (2010).Student recruitment marketing in South Africa - An exploratory study into the adoption of a relationship orientation.African Journal of Business Management, 4(4), 435-447.

8 Chen, C., \&Zimitat, C. (2006).Understanding Taiwanese students' decision-making factors regarding Australian international higher education.International Journal of Educational Management, 20(2), 91-100.

$9 \quad$ Enache, I.-C. (2011). Marketing higher education using the 7Ps framework. Bulletin of the Transilvania University of Braşov, 4(1), 23-30.

10 Ivy, J. (2008). A new higher education marketing mix: the 7Ps for MBA marketing. International Journal of Educational Management, 22(4), 288-299.

11 Kallio, R. (1995). Factors influencing the college choice decisions of graduate students. Research in Higher Education, 36(1), 109-124. 
2010; $;^{12}$ Kusumawati \& Perera, 2010 $;^{13}$ Lay \& Maguire, $1981 ;{ }^{14}$ Maringe, 2006; $;^{15}$ Nicholls \& Harris, $1995 ;{ }^{16}$ Price, Matzdorf, Smith, \& Agahi, 2003; ${ }^{17}$ Rafiq \& Ahmed, $1995 ;{ }^{18}$ Rodić, Kiš, \& Čileg, 2012; ${ }^{19}$ Vrontis, Thrassou, \& Melanthiou, $2007^{20}$ ).

As early as 1981, Lay and Maguire used factor analysis to reveal seven elements which influence the choice of a faculty. They named those seven factors: financial aid, parent's preference, specific academic programs, size of the school, location of the campus, athletic facilities, and social activities. Kallio (1995) has isolated four factors by using factor analysis, based on 31 variables associated with the student's choice of a faculty. Those factors were: academic, work, spouse and social. The first factor encompassed most variables, and some of them are related to institution's reputation and location, as well as the quality of library facilities and teaching. These variables also appear in some other studies. Price and his associates (Price et al., 2003) have based their research on the importance of faculty's resources, location and service ambiance. Some of the variables which proved to be very important were: desired study program, availability of computers, quality of library facilities, good professors' reputation, availability of group work areas and availability of 'quiet' areas. Maringe ${ }^{21}$ (2006) conducted a research in which the students were asked to rank 30 variables by the significance of their impact on student's faculty choice decisions. These variables were combined into seven categories, and subsequently, the significance of each category was determined according to the mean value and standard deviation. The categories were named: program, price, promotion, people, prospects, prominence, and place. According to the results of this research, the most important marketing mix instruments for institu-

12 Khan, S. N., \& Qureshi, I. M. (2010).Impact of promotion on students' enrollment: A case of private schools in Pakistan. International Journal of Marketing Studies, 2(2), 267-274.

13 Kusumawati, A., \&Perera, N. (2010).Exploring student choice criteria for selecting an Indonesian public university: A preliminary finding.ANZMAC 2010 Doctoral Colloquium, 1-27.

14 Lay, R., \& Maguire, J. (1981). Coordinating market and evaluation research on the admissions rating process. Research in Higher Education, 14(1), 71-85.

15 Maringe, F. (2006). University and course choice: Implications for positioning, recruitment and marketing. International Journal of Educational Management, 20(6), 466-479.

16 Nicholls, J., \& Harris, J. (1995). Marketing higher education: the MBA experience. International Journal of Educational Management, 9(2), 31 - 38.

17 Price, I., Matzdorf, F., Smith, L., \&Agahi, H. (2003).The impact of facilities on student choice of university.Facilities, 21(10), 212-222.

18 Rafiq, M., \& Ahmed, P. (1995).Using the 7Ps as a generic marketing mix: an exploratory survey of UK and European marketing academics.Marketing Intelligence \& Planning, 13 (9), 4-15.

19 Rodić, V., Kiš, T., \&Čileg, M. (2012).Determinants of high school graduates' choice of faculty. Technics Technologies Education Management / TTEM ISSN: 1840-1503, 7(4), 1655-1662.

20 Vrontis, D., Thrassou, A., \&Melanthiou, Y. (2007).A contemporary higher education student-choice model for developed countries.Journal of Business Research, 60(9), 979-989.

21 Maringe, F. (2006). University and course choice: Implications for positioning, recruitment and marketing. International Journal of Educational Management, 20(6), 466-479. 
tions of higher education were: program, price, and place, respectively. Ivy ${ }^{22}$ (2008) has conducted a research similar to Maringe ${ }^{23}$ (2006), with the exception of using 25 variables related to different marketing tools used by higher education institutions. These variables were merged into seven factors by using factor analysis and afterwards ranked by significance. The names of these variables are: program, price, promotion, people, prospects, prominence, and premium. The results of this research indicate that the most important factors are program, prominence, and price, respectively. In order to discover the factors affecting the decision of the students, a research (Rodić et al., $2012^{24}$ ) was conducted on a sample of high school graduates, examining 36 variables related to different marketing tools. These variables were grouped into seven elements named: faculty offer, service environment and image, social networking, family influence and the media, promotion, price and influence of friends. The first three factors were found as most important. The reviewed literature places the program, the price, and the prominence as the most important issues in the determination of the faculty choice. This paper seeks for an explanation if these factors are present and in which order in Vojvodina, where general economic and social conditions in the country, which is still being under the process of transition, differ from more developed countries.

\section{Research methodology}

The subject of this research is to determine the factors that influence students' decisions related to faculty choice. The fundamental goal and purpose of the conducted research is to determine whether traditional marketing mix can be used to influence a student's decision related to the choice of faculty within the University of Novi Sad. If it cannot be used in that form, the question is whether there is a different mix of instruments that can influence the students' decisions. The research needs to provide an answer to the question which marketing mix instrument has the greatest impact on the decision which faculty to enroll. This research attempts to contribute to the clarification of issues related to the implementation of marketing activities in higher education institutions and highlight the growing need for wider application of the mentioned activities. Based on the goals mentioned, the primary task has been determined. The primary task is to resolve the parameters that decisively influence the decision to enroll at a certain faculty, and group them into specific components of a marketing mix.

22 Ivy, J. (2008). A new higher education marketing mix: the 7Ps for MBA marketing. International Journal of Educational Management, 22(4), 288-299.

23 Maringe, F. (2006). University and course choice: Implications for positioning, recruitment and marketing. International Journal of Educational Management, 20(6), 466-479.

24 Rodić, V., Kiš, T., \&Čileg, M. (2012).Determinants of high school graduates' choice of faculty.Technics Technologies Education Management / TTEM ISSN: 1840-1503, 7(4), $1655-1662$ 


\subsection{Respondent sample}

The University of Novi Sad was chosen for the population of the research, and the sample included students from the Faculty of Economics in Subotica (100 students, or $12.8 \%$ of the selected sample), the Faculty of Education in Sombor (136 or 17.4\%), the Faculty of Sciences (109 students, or 13.9\%), the Faculty of Philosophy (209 students, or 26.7\%), the Faculty of Technical Sciences (107 or 13.7\%) and the Faculty of Law in Novi Sad (122, or 15.6\%). It is a random sample or, to be exact, simple random sample, which means that all entities of the population have equal probability of being in the sample. As stated, the research included 783 students from the University of Novi Sad, of which 499 (63.7\%) had their studies funded by the state budget and 284 paid tuition fees. Most students in the sample were females, 632 ( $80.7 \%$ of them), to be exact, and most were aged between 21 and 23. According to demographic characteristics, the majority of students, 580 of them (74.1\%), lived in urban areas. According to the variable "success in foregoing studies", the sample contained most students with a grade point average ranging from 7.5 to 8.4 (365 or $45.5 \%$ of total) and $226(28.9 \%)$ students with a grade point average ranging from 8.5 to $9.5^{25}$. Of all the students, 176 attended the first and 166 the second year; the answers they gave were the most reliable; others enrolled to higher years of the faculty, and the possible biases were minimized by strongly asking the respondents to base their answers not on the experiences they had got during their studies but on considerations prior to their enrolment.

\section{2.. Research instrument}

Specific data and facts were acquired in writing by using the survey technique. A non-standardized survey questionnaire, containing questions of both open and closed type, was used as an instrument of the research. As mentioned above, the questionnaire that was applied in the survey was used for measuring students' attitudes towards 26 different marketing tools, covering all the main elements of the traditional marketing mix for services. The questionnaire was constructed based on previously conducted research (Cubillo, Sánchez, \& Cerviño, 2006; ${ }^{26}$ Ivy, 2008; Kallio, $1995 ;{ }^{27}$ Maringe, $2006 ;{ }^{28}$ Price et al., $\left.2003^{29}\right)$. A five-point Likert scale was

25 Note: In Serbian system of higher education, evaluation score scale is from 6 to 10.

26 Cubillo, J. M., Sánchez, J., \&Cerviño, J. (2006).International students' decision-making process.International Journal of Educational Management, 20(2), 101-115.

27 Ivy, J. (2008). A new higher education marketing mix: the 7Ps for MBA marketing. International Journal of Educational Management, 22(4), 288-299.

28 Maringe, F. (2006). University and course choice: Implications for positioning, recruitment and marketing. International Journal of Educational Management, 20(6), 466-479.

29 Price, I., Matzdorf, F., Smith, L., \&Agahi, H. (2003):The impact of facilities on student choice of university.Facilities, 21(10), 212-222. 
used for this purpose. The students were asked to give grades of importance from 1 to 5 ( 1 very unimportant; 5 - very important). The reliability of the measurement scale was presented in its degree of resistance to random errors. Cronbach's alpha coefficient was used in order to determine the extent of consistency of the results provided by the scale. Coefficients exceeding 0.7 were considered acceptable, and coefficients exceeding 0.8 were considered good (Ivy, 2008 ${ }^{30}$ ). Cronbach's alpha coefficient computed for the 26 variables related to different marketing tools, which were included in this research, was 0.809 , and therefore it can be concluded that the measurement scale that was used was reliable. The item-to-total correlation was used to identify variables that may have not been consistent with other variables that were measured. In this research, all items were proved to have significant correlations with one another, which points to a high level of inner consistency.

\subsection{Data Processing}

Based on the subject of research, the specific goals and tasks, the research was executed by analyzing prior theoretical views, as well as by empirical method. The principal components factor analysis classified those variables which were highly correlated within a single independent factor. Such classification of similar tools produces a new, reduced number of variables, which will afterwards be used to construct a new marketing mix for institutions of higher education. The data analysis was performed by using the statistical package for data analysis (SPSS 17.0 - Statistical Package for Social Sciences - for Windows).

\section{Research results}

The main elements included in this study, with quantitative indices are shown in table 1.It is an interesting finding that the highest grade, i.e. most relevant importance has been given to Delayed payment (4.0524) with the second highest level of agreement between respondents (the second smallest variation coefficient of 0.2745 ), reflecting thus the current economy situation of the population in general in this country. The next highest grades (with a high level of agreement) have been given to the statement that "State-founded faculty is more secure for future employment" (the majority of companies and especially public corporations even refuse to interview candidates from privately owned faculties for employment) and "Faculty tradition gives good image". Some faculties persistently apply for promotions in high schools, spending a lot of funds, but it comes out that this is of the least importance to the future students although here we have the most divergent answers (highest variation coefficient of 0.6199 ).

30 Ivy, J. (2008): A new higher education marketing mix: the 7Ps for MBA marketing. International Journal of Educational Management, 22(4), 288-299. 
Prior to the implementation of the principal component analysis (PCA), the data was assessed in terms of suitability for factor analysis. The value of KaiserMeyer-Olkin parameter was verified for this purpose, reaching a value of 0.854 , which exceeds the recommended value of 0.6 (Kaiser, $1970^{31}, 1974^{32}$ ). Bartlett's test of sphericity (Bartlett, 1954 ${ }^{33}$ ) reached statistical significance (sig. level of 0.000), therefore, the use of factor analysis was justified. Eigen values are often used in order to identify the number of factors which should be created. According to this criterion, the factors with a characteristic value exceeding 1 are retained (Acker et al., 2008 ${ }^{34}$ ). Principal components analysis detected the presence of seven components with Eigen values exceeding 1 (6.051, 2.258, 1.467, 1.403, 1.292, 1.241, 1.157). These seven components account for total $52.2 \%$ of the variance. By use of communalities $\left(h^{2}\right)$, as a measurement of each variable's involvement in the entire system, it could be determined that all of the variables have significant parts in defining the system. "Faculty website" and "Faculty branch" have somewhat lower communalities.

After the rotation of the main components had been performed in order to get a simpler solution using the oblimin method, the result was a set of variables of marketing mix for institutions of higher education (table2), which confirmed the actual existence of latent dimensions of marketing mix, and can be interpreted very reliably in accordance with many researchers(Cubillo et al., 2006; $;^{35}$ Ivy, 2008; ${ }^{36}$ Kallio, $1995 ;^{37}$ Maringe, $2006 ;^{38}$ Price et al., $2003^{39}$ ). By use of principal component analysis and oblimin method of rotation, seven factors were singled out. These seven factors show correspondence with the traditional 7P marketing mix in most factors.

The first factor encompasses variables related to professors' accessibility, courtesy of the staff, teaching methods, professors' expertise and educational service. These are, at the same time, variables with a high projection on this factor, hence this factor is considered to be very important to the students when deciding which

$31 \quad$ Kaiser H (1970).A second generation Little Jiffy.Psychometrika. 35: 401-415.

32 Kaiser H (1974): An index of factorial simplicity.Psychometrika.39: 31-36.

33 Bartlett, M. (1954): A note on the multiplying factors for various chi square approximations. J. Royal Stat. Soc.. 16: 296-298.

34 Acker, D.A., Kumar V., Dej D.S. (2008).: Marketing Research.Beograd. Faculty of Economics

35 Cubillo, J. M., Sánchez, J., \&Cerviño, J. (2006): International students' decision-making process.International Journal of Educational Management, 20(2), 101-115.

36 Ivy, J. (2008). A new higher education marketing mix: the 7Ps for MBA marketing. International Journal of Educational Management, 22(4), 288-299.

37 Kallio, R. (1995): Factors influencing the college choice decisions of graduate students. Research in Higher Education, 36(1), 109-124.

38 Maringe, F. (2006): University and course choice: Implications for positioning, recruitment and marketing. International Journal of Educational Management, 20(6), 466-479.

39 Price, I., Matzdorf, F., Smith, L., \&Agahi, H. (2003):The impact of facilities on student choice of university.Facilities, 21(10), 212-222. 
faculty to enroll. This factor, besides the "people" component, also possesses elements of the first instrument of the traditional marketing mix, which is a product, or in this case, service provided by these institutions. Based on all stated above, the first factor can be named "People". The second factor encompasses variables related to the interior and exterior of the faculty building and the general impression during the stay. The first two variables have an exceptionally high projection on the factor. The third variable is related to the students' overall impression during their stay at the faculty, which should be pleasant and relaxing. This variable has somewhat lower, but not less significant projection on this factor. All three variables are related to one of the instruments of the traditional 7P marketing mix, the socalled "Physical Evidence", and that is why the second factor was named so. The third factor encompasses the variables related to the faculty promotion, media campaign and faculty flyers. The variable "Faculty promotion" is related to promotion of the faculty in secondary schools and this variable has a high level of projection on this factor. All integrated marketing communications carried out through traditional media (TV, radio, newspapers, etc.) are included in the "media campaign" variable. Promotion through a website has not been covered by this factor. This is the reason why the third factor, although bearing the name "Promotion", is not equivalent to the traditional instrument of the 7P marketing mix. The fourth factor incorporates the variables related to the image, tradition and website of a faculty, as well as the type of financing of the faculty. The variable "State-founded faculty" is related to the belief that a state-founded faculty provides greater certainty for future employment. This variable has a high projection on the factor and demonstrates the advantage of state-founded faculties in relation to private faculties. Such students' attitude is still very strong in Serbia, compared to abroad, where private faculties are given advantage. The variable "Faculty image" points towards the significance of a faculty's good image and reputation. This variable has a high projection on the factor, and therefore represents an important element within the student's choice of faculty. Based on the previous conclusions, the fourth factor was named "Image". The fifth factor includes the variables related to the quality of library services and their facilities, the quality of Student affairs office's service, computer classrooms and modern technology. The variable "Library service" has the greatest projection on the factor, followed by the variables "Quality of library facilities", having a high projection on the factor, and "Student affairs office's service", with a moderate projection on the factor. Variables with a lower projection on this factor are "Computer classrooms" and "Modern technology". Based on the variables it encompasses, the fifth factor can be named "Resources and Extra Services". The sixth factor includes the following variables related to the second branch: the city as a place of a faculty's residence and distance learning. The variable "Second branch", which is related to the notion that students wish to enroll on a certain faculty in another town, has a high projection on the factor. The variable "City - location of the faculty", which is associated with the importance of studying in a particular town, also has a high 
projection on the factor, while "Distance learning" has somewhat lower projection. Based on the above, the sixth factor was named "Place", because of the equivalency between the elements of this factor and the traditional marketing mix instrument. The seventh factor includes variables related to delayed payment, tuition costs, and faculty branch. The variable "Delayed payment" possesses a high projection on the factor, while the variable "Tuition costs" has a medium projection on the factor. The variable "Faculty branch" has a low projection on the factor, and its variance is divided into two factors. It appears in the seventh factor with somewhat greater factorial weight, and to some degree lower factorial weight in the second. Owing to variables with a high projection, the seventh factor was named "Price". Such name was given to the factor because its elements match the instrument of the traditional $7 \mathrm{P}$ marketing mix bearing the same name.

Several variables have divided their factor weight on two factors, which can be interpreted very clearly. Within the first factor named "People", the variable related to professor's expertise is particularly interesting, since its variance is divided into two factors. This variable appears in the first factor with somewhat greater factorial weight, and to some extent in the third factor, named "Image". This could be explained by the fact that the students perceive professors' expertise as a part of "People" component of the marketing mix, but also find that professors" expertise can influence the image of a faculty, i.e. that this is one of the main elements of building the reputation of institutions of higher education. The variable "Modern technology", which is related to faculty's resources in modern technology, distributes its variance onto two factors, too. It appears in the fifth factor with somewhat greater factorial weight, and with slightly less factorial weight in the third factor, called "Promotion". This situation can be explained by the fact that the students perceive the need for modern technology as a compulsory part of a faculty's resources, but also believe that modern technological resources should be particularly accentuated during faculty's promotional activities. Moreover, the students perceive modern technological resources as an addition to traditional instruments of marketing communications, which are included in the third factor. In such way, they express their need for promotion of the faculties through modern media. The variable "Faculty's tradition" concerns the idea that tradition has a positive impact on a faculty's image, and its variance is divided into two factors. This variable appears in the fourth factor with somewhat greater factorial weight, and with slightly lesser factorial weight in the second factor, named "physical evidence". This situation can be accounted for by the fact that the students consider tradition to be influential to a faculty's image, and further, by the fact that they become aware of the faculty's tradition based on their experience of the ambiance inside the faculty and the external appearance of the institution. The faculties can make use of their long tradition when designing the interiorof their buildings. Students' impressions during their stay in such environment can further facilitate the increase of these institutions' reputation. 


\section{Discussion}

On the basis of the calculated mean value, it can be concluded that "Promotion", as a marketing mix instrument, is the least important to students in their decision making process about which faculty to enroll $(M=2,08 ; S D=0,81)$. It can be further stated that this factor comprises only the traditional marketing mix instruments, while today's students devote more attention to electronic media. Such result appears in several other studies (Ivy, 2008; ${ }^{40}$ Maringe, 2006; ${ }^{41}$ Mazzarol, 1998; ${ }^{42}$ Rodić et al., 2012 $2^{43}$ ) where the "Promotion" factor could be found at the penultimate position. This serves as a warning for institutions which spend vast sums of money on commercial messages and promotional activities in order to attract students. However, this does not mean that those activities should be discontinued, but redirecting the strategy towards a better care for students' needs can help institutions to shift their market position. An example of this is a faculty from the south of the United Kingdom, which developed a program called "Student Ambassador", where each student that applies is partnered with a student trained to help them if they have any questions, 'from applying to enrolment'(Maringe, 2006; ${ }^{44}$ Rodić \& Lukić, 2012 ${ }^{45}$ ). That way, the faculty management ensures that the students will receive appropriate service, and at the same time, the workload of student affairs office, which is involved in a lot of administrative tasks at that time, will be lessened.

The factor named "Image" appears as the far most important of all elements $(M=3,60 ; S D=0,81)$. The institution's image represents a set of attitudes, ideas, and impressions that potential students have related to that educational institution (Kotler \& Fox, $1995^{46}$ ). Their attitude towards an institution's image is shaped by "word-of-mouth" communication, previous experience and institution's marketing activities (Ivy, 2008 ${ }^{47}$ ). The aspects of the institutional image are highly ranked in

40 Price, I., Matzdorf, F., Smith, L., \&Agahi, H. (2003): The impact of facilities on student choice of university.Facilities, 21(10), 212-222.

${ }_{41}$ Maringe, F. (2006). University and course choice: Implications for positioning, recruitment and marketing. International Journal of Educational Management, 20(6), 466-479.

42 Mazzarol, T. (1998): Critical success factors for international education marketing. International Journal of Educational Management, 12(4), 163 - 175.

43 Rodić, V., Kiš, T., \&Čileg, M. (2012).Determinants of high school graduates' choice of faculty. Technics Technologies Education Management / TTEM ISSN: 1840-1503, 7(4), 1655-1662.

44 Maringe, F. (2006): University and course choice: Implications for positioning, recruitment and marketing. International Journal of Educational Management, 20(6), 466-479.

45 Rodić, V., \&Lukić, N. (2012): Specific features of the application of the marketing mix concept in institutions of higher education..Norma, 17(2), 257-268.

46 Kotler, P., \& Fox, K. (1995): Strategic Marketing for Educational Institutions. Englewood Cliffs, New Yersey: Prentice Hall Inc.

47 Ivy, J. (2008). A new higher education marketing mix: the 7Ps for MBA marketing. International Journal of Educational Management, 22(4), 288-299. 
many research studies (Cubillo et al., 2006; $;^{48}$ Ivy, 2008; ${ }^{49}$ Maringe, $2006 ;{ }^{50}$ Price et al., $2003^{51}$ ). Price et al. ${ }^{52}(2003)$ used the term "Good teaching reputation" for the image of an institution, and that element was ranked fourth (of total 16 elements), for two years in a row, which is high. Maringe ${ }^{53}$ and Ivy ${ }^{54}$ named the mentioned factor "Prominence". This factor had comprised the following variables: "Institution's image", "Professors' reputation" and "Faculty website". Maringe ${ }^{55}$ placed this factor fourth on the list (of seven in total), while $\operatorname{Ivy}^{56}$ (2008) placed it in the high-ranked second place.

By significance, the first factor named "People", can be found in the high second place $(M=3,12 ; S D=0,90)$. Such high ranking of this factor, in contrast to other researchers(Ivy, 2008; Maringe, 2006), where this particular factor had very low impact on the students' decisions, can be accounted for in various ways. One of the reasons why the students of the University of Novi Sad feel the need to receive a better educational service is probably their discontent with the previously received service. The students' need to receive this service from expert and accessible teaching staff, who take advantage of various teaching techniques, is also a consequence of their previous lecturers' indifference.

"Place" is the second by significance $(\mathrm{M}=3,13 ; \mathrm{SD}=0,75)$, and is positioned at a level similar to the instrument "People". Based on the evaluated importance of "Place" as a marketing mix instrument and the variables included in this factor, it can be concluded that students find that the way the knowledge is distributed is very important. It had been previously concluded that the town, as a place of the faculty location is not of great significance during the process of faculty selection by the students, but also that distance learning, as one of the means of knowledge distribution, is presently in high demand. Price et al. ${ }^{57}(2003)$

$48 \quad$ Cubillo, J. M., Sánchez, J., \&Cerviño, J. (2006): International students' decision-making process.International Journal of Educational Management, 20(2), 101-115.

49 Ivy, J. (2008). A new higher education marketing mix: the 7Ps for MBA marketing. International Journal of Educational Management, 22(4), 288-299.

50 Maringe, F. (2006): University and course choice: Implications for positioning, recruitment and marketing. International Journal of Educational Management, 20(6), 466-479.

51 Price, I., Matzdorf, F., Smith, L., \&Agahi, H. (2003):The impact of facilities on student choice of university.Facilities, 21(10), 212-222.

52 Price, I., Matzdorf, F., Smith, L., \&Agahi, H. (2003): The impact of facilities on student choice of university.Facilities, 21(10), 212-222.

53 Price, I., Matzdorf, F., Smith, L., \&Agahi, H. (2003): The impact of facilities on student choice of university.Facilities, 21(10), 212-222.

54 Maringe, F. (2006): University and course choice: Implications for positioning, recruitment and marketing. International Journal of Educational Management, 20(6), 466-479.

55 Maringe, F. (2006): University and course choice: Implications for positioning, recruitment and marketing. International Journal of Educational Management, 20(6), 466-479.

56 Ivy, J. (2008): A new higher education marketing mix: the 7Ps for MBA marketing. International Journal of Educational Management, 22(4), 288-299.

57 Price, I., Matzdorf, F., Smith, L., \&Agahi, H. (2003): The impact of facilities on student choice of university.Facilities, 21(10), 212-222. 
pays particular attention to location, besides physical evidence, thus concluding that the location is of great importance to students' decisions. Cubillo et al. ${ }^{58}(2006)$ highlights the importance of a faculty location, as well as the importance of this town's image. Furthermore, he points out the fact that significant elements are: the town size, the cost of living and the town's surroundings. The factor "Price" appears in the fifth place $(\mathrm{M}=3.05 ; \mathrm{SD}=$ 0,83), at a level similar to one of "Physical evidence". These two instruments are of medium importance to a student's choice of a faculty. In the previous studies (Maringe, 2006; ${ }^{59} \mathrm{Ivy}$, $2008^{60}$ ), "Price" proved to be a very important marketing mix instrument. In Maringe's ${ }^{61}$ study, this factor was ranked second, and in Ivy's ${ }^{62}$ study, third on the list by significance. The reason that "Price" has a somewhat lesser level of significance can be ascribed to the fact that $60 \%$ of the respondents in this research were students whose studies were financed by the national budget, and therefore do not assign that much importance to the price element. On the other hand, previous researches were conducted in countries where studies are less frequently or not ever financed by a national budget. "Physical evidence" as a factor can be found in the sixth place by significance $(\mathrm{M}=3,02 ; \mathrm{SD}=1,01)$, but just like "Price", has an above-average result. There was no such factor in previous researchers because some of the variables associated with this marketing mix instrument were categorized under some different factors. In Maringe's ${ }^{63}$ study (2006), "Campus accommodation", "Residential requirements" and "Facilities" can be found within "Place" factor, and hold a high third place by significance. In Ivy's ${ }^{64}$ study (2008), "Residential requirements" and "Accommodation" are placed within "Premium" factor and hold the last place by significance. In Price's ${ }^{65}$ study variables "Availability of 'quiet' areas" and "Availability of group work areas" were rated as very important by the students. Unlike Maringe and Ivy, who had explored only the variables related to the ambiance in student dormitories, Price et al. ${ }^{66}$ devoted special attention to this element. He considers that physical evidence, as well as additional

58 Cubillo, J. M., Sánchez, J., \&Cerviño, J. (2006): International students' decision-making process.International Journal of Educational Management, 20(2), 101-115.

59 Maringe, F. (2006): University and course choice: Implications for positioning, recruitment and marketing. International Journal of Educational Management, 20(6), 466-479. Ivy, J. (2008): A new higher education marketing mix: the 7Ps for MBA marketing. International Journal of Educational Management, 22(4), 288-299.

${ }_{61}$ Maringe, F. (2006): University and course choice: Implications for positioning, recruitment and marketing. International Journal of Educational Management, 20(6), 466-479.

62 Ivy, J. (2008): A new higher education marketing mix: the 7Ps for MBA marketing. International Journal of Educational Management, 22(4), 288-299.

63 Maringe, F. (2006). University and course choice: Implications for positioning, recruitment and marketing. International Journal of Educational Management, 20(6), 466-479.

${ }^{64}$ Ivy, J. (2008). A new higher education marketing mix: the 7Ps for MBA marketing. International Journal of Educational Management, 22(4), 288-299.

${ }^{65}$ Price, I., Matzdorf, F., Smith, L., \&Agahi, H. (2003):The impact of facilities on student choice of university.Facilities, 21(10), 212-222.

66 Price, I., Matzdorf, F., Smith, L., \&Agahi, H. (2003):The impact of facilities on student choice of university.Facilities, 21(10), 212-222. 
services within the campus, represent a very important factor when choosing a faculty. According to the results of his research, the most important factor is associated with social life within the campus, along with its surrounding. The factor "Facilities and extra services" is located on the medium level of importance $(M=3,07 ; S D=0,79)$, closely to the same level as "Price" and "Physical evidence". This factor does not appear in the same form in previous studies, but some of the variables match the variables found in the previous studies. In Price's ${ }^{67}$ study variables named "Availability of computers" and "Quality of library facilities" were ranked second and third by significance. In Ivy's ${ }^{68}$ study the variable "Computer facilities" is placed within a factor named "Premium", which is ranked last by significance. The author justifies this result by the fact that most students view upon some of the variables as expected, and therefore do not assign them much significance. Hence, many students would be surprised if they were unable to access computer labs in some cases, so this element is nonetheless considered to be very important during the process of faculty selection. In our case, computer labs are still not available to students of all faculties, making this factor still very important when it comes to the students of the University of Novi Sad.

\section{Conclusion}

Marketing is a business activity which is becoming more immanent to non-profit organizations, such of which are institutions of higher education. The need for marketing is caused by the intensification of market competition between faculties. By regularly conducting surveys, faculties can gain insight into students' opinions related to the faculty, as well as the factors that influenced them to enroll on a certain faculty. Based on their attitudes, it is possible to recognize the marketing mix instruments with the greatest influence on their decisions. Due to the specificity of the institutions of higher education, it is impossible to apply this concept in its traditional form, which is associated with the 7P marketing mix for services. Based on the conducted research, the factors that match the five marketing mix instruments were outlined. Those are: "Price", "Place", "Promotion", "People" and "Physical evidence", with the exception that "Promotion" does not incorporate electronic media, which are covered by the traditional instrument. The other two factors were named "Image" and "Resources and extra services", while the latter has common ground with the first traditional instrument, Product/Service".

Based on the results of the conducted research, it can be concluded that the application of marketing mix concept to an institution of higher education is absolutely justified, but also that it is necessary to revise the classic concept, with a consideration

67 Price, I., Matzdorf, F., Smith, L., \&Agahi, H. (2003).The impact of facilities on student choice of university.Facilities, 21(10), 212-222.

68 Ivy, J. (2008): A new higher education marketing mix: the 7Ps for MBA marketing. International Journal of Educational Management, 22(4), 288-299. 
for special features of each institution. It is the image that presents itself as the most important factor for the students' choice of a faculty. Students give most attention to a faculty website, which represents a mirror image of that institution. This can serve as a warning to many faculties in Serbia, which are still unaware of the importance of a well-maintained, accessible and up-to-date website. Students rate the image of a faculty based on professors' expertise, faculty's tradition, as well as the previous experience they had with the faculty. In their empirical research, Miljković and Kovačevićc9 ${ }^{6}$ confirmed that students opt for a faculty based on its image, which is fashioned by means of marketing mix instruments. Service quality has the greatest effect on the shaping of a faculty's image, while knowledge applicability is ranked best, from the students' perspective. To what extent will these activities improve the operation of institutions of higher education, and causally, lead to the increase in a number of enrolled students, depends on the readiness of the faculties' management to assign more significance to this problem than so far.

\section{References}

- Acker, D.A., Kumar V., Dej D.S. (2008): Marketing Research. Beograd. Faculty of Economics

- Bartlett, M. (1954). A note on the multiplying factors for various chi square approximations. J. Royal Stat. Soc.. 16: 296-298.

- Beneke, J., \& Human, G. (2010). Student recruitment marketing in South Africa - An exploratory study into the adoption of a relationship orientation. African Journal of Business Management, 4(4), 435-447.

- Booms, B.H., Bitner MJ (1981). Marketing strategies and organization structures for service firms. In Marketing of Services, Donnelly J, W.R. George (eds), American Marketing Association

- Chen, C., \& Zimitat, C. (2006). Understanding Taiwanese students' decisionmaking factors regarding Australian international higher education. International Journal of Educational Management, 20(2), 91-100.

- Cubillo, J. M., Sánchez, J., \& Cerviño, J. (2006): International students' decision-making process. International Journal of Educational Management, 20(2), 101-115.

- $\quad$ Enache, I.-C. (2011): Marketing higher education using the 7Ps framework. Bulletin of the Transilvania University of Braşov, 4(1), 23-30.

- Ivy, J. (2008): A new higher education marketing mix: the 7Ps for MBA marketing. International Journal of Educational Management, 22(4), 288-299.

- Kaiser H (1970): A second generation Little Jiffy. Psychometrika. 35: 401-415.

- Kaiser H (1974): An index of factorial simplicity. Psychometrika.39: 31-36.

69 Miljković, J., Kovacević, J.M. (2011): Elements of marketing mix as factors of choosing institution of higher education. Andrag.Studies. 1: 135-156. 
- Kallio, R. (1995): Factors influencing the college choice decisions of graduate students. Research in Higher Education, 36(1), 109-124.

- Khan, S. N., \& Qureshi, I. M. (2010): Impact of promotion on students' enrollment: A case of private schools in Pakistan. International Journal of Marketing Studies, 2(2), 267-274.

- $\quad$ Kotler, P., \& Fox, K. (1995): Strategic Marketing for Educational Institutions. Englewood Cliffs, New Yersey: Prentice Hall Inc.

- Kusumawati, A., \& Perera, N. (2010): Exploring student choice criteria for selecting an Indonesian public university: A preliminary finding. ANZMAC 2010 Doctoral Colloquium, 1-27.

- $\quad$ Lay, R., \& Maguire, J. (1981): Coordinating market and evaluation research on the admissions rating process. Research in Higher Education, 14(1), 71-85.

- Maringe, F. (2006): University and course choice: Implications for positioning, recruitment and marketing. International Journal of Educational Management, 20(6), 466-479.

- Mazzarol, T. (1998): Critical success factors for international education marketing. International Journal of Educational Management, 12(4), 163 - 175.

- Miljković, J., Kovacević, J.M. (2011): Elementsofmarketing mix as factors of choosing institution of higher education. Andrag. Studies. 1: 135-156.

- Nicholls, J., \& Harris, J. (1995): Marketing higher education: the MBA experience. International Journal of Educational Management, 9(2), 31 - 38.

- Price, I., Matzdorf, F., Smith, L., \& Agahi, H. (2003): The impact of facilities on student choice of university. Facilities, 21(10), 212-222.

- $\quad$ Rafiq, M., \& Ahmed, P. (1995): Using the 7Ps as a generic marketing mix: an exploratory survey of UK and European marketing academics. Marketing Intelligence \& Planning, 13 (9), 4-15.

- Rodić, V., Kiš, T., \& Cileg, M. (2012): Determinants of high school graduates' choice of faculty. Technics Technologies Education Management / TTEM ISSN: 1840-1503, 7(4), 1655-1662.

- Rodić, V., \& Lukić, N. (2012): Specific features of the application of the marketing mix concept in institutions of higher education..Norma, 17(2), 257268.

- Vasiljev, S. (2005): Marketing principi (p. 418). Novi Sad: Prometej.

- Vrontis, D., Thrassou, A., \& Melanthiou, Y. (2007): A contemporary higher education student-choice model for developed countries. Journal of Business Research, 60(9), 979-989. 


\section{Appendix}

Table 1. Average grades, standard deviations and variation coefficients

\begin{tabular}{|c|l|c|c|c|}
\hline $\begin{array}{c}\text { Initial } \\
\text { coding }\end{array}$ & \multicolumn{1}{|c|}{ VARIABLE } & Average & S. Dev. & Var. coeff. \\
\hline Q1 & MODERN TECHNOLOGY & 2.8404 & 1.0940 & 0.3851 \\
\hline Q2 & LIBRARY RESOURCES & 3.1379 & 1.0596 & 0.3377 \\
\hline Q3 & EDUCATIONAL SERVICE & 3.0332 & 1.0952 & 0.3611 \\
\hline Q4 & COURTEOUS STAFF & 3.2797 & 1.1060 & 0.3372 \\
\hline Q5 & COMPUTER CLASSROOMS AND THE INTERNET & 3.3001 & 1.1692 & 0.3543 \\
\hline Q6 & TUITION COSTS & 2.2261 & 1.3509 & 0.6069 \\
\hline Q7 & DELAYED PAYMENT & 4.0524 & 1.1124 & 0.2745 \\
\hline Q8 & IMPORTANCE OF THE CITY - ANY FACULTY & 3.5121 & 1.4086 & 0.4011 \\
\hline Q9 & DISTANCE LEARNING & 2.9540 & 1.4207 & 0.4809 \\
\hline Q10 & FACULTY BRANCH & 2.8595 & 1.4018 & 0.4902 \\
\hline Q11 & EXTERIOR OF THE FACULTY BUILDING & 3.3895 & 1.1854 & 0.3497 \\
\hline Q12 & FACULTY INTERIOR & 2.9310 & 1.2298 & 0.4196 \\
\hline Q13 & IMPRESSION DURING THE STAY & 2.7369 & 1.0991 & 0.4016 \\
\hline Q14 & FACULTY PROMOTION IN YOUR HIGH SCHOOL & 1.5568 & 0.9650 & 0.6199 \\
\hline Q15 & FACULTY FLYERS AND INFORMATION BULLETINS & 2.7280 & 1.2508 & 0.4585 \\
\hline Q16 & STUDENT AFFAIRS OFFICE'S SERVICE & 2.8812 & 1.2895 & 0.4475 \\
\hline Q17 & FACULTY WEBSITE & 3.3883 & 1.4070 & 0.4152 \\
\hline Q18 & MEDIA CAMPAIGN & 1.9745 & 1.0694 & 0.5416 \\
\hline Q19 & FACULTY TRADITION GIVES GOOD IMAGE & 3.7344 & 1.0075 & 0.2698 \\
\hline Q20 & $\begin{array}{l}\text { STATE-FOUNDED FACULTY IS MORE SECURE } \\
\text { FOR FUTURE EMPLOYMENT }\end{array}$ & 3.8186 & 1.2267 & 0.3212 \\
\hline Q21 & PROFESSORS' EXPERTISE BEING AT HIGH LEVEL & 3.3780 & 1.1108 & 0.3288 \\
\hline Q22 & IMPORTANCE OF THE FACULTY - ANY CITY & 2.9374 & 1.3868 & 0.4721 \\
\hline Q23 & PROFESSORS' ACCESSIBILITY & 2.9246 & 1.1931 & 0.4079 \\
\hline Q24 & LIBRARY SERVICE & 3.1941 & 1.1671 & 0.3654 \\
\hline Q25 & INNOVATIVE TEACHING METHODS & 2.9706 & 1.1659 & 0.3925 \\
\hline Q26 & FACULTY IMAGE & 3.4687 & 1.1619 & 0.3350 \\
\hline
\end{tabular}

Source: Authors' calculations 
Table 2. Pattern matrix of variables of marketing mix of institutions of higher education

\begin{tabular}{|c|c|c|c|c|c|c|c|}
\hline VARIABLE & A1 & $\mathrm{A} 2$ & A3 & A4 & A5 & A6 & A7 \\
\hline PROFESSORS' ACCESSIBILITY (LJ1) & .900 & -.006 & -.001 & .088 & .040 & -.029 & .024 \\
\hline COURTEOUS STAFF (LJ2) & .871 & .018 & -.058 & -.014 & -.021 & -.047 & .062 \\
\hline TEACHING METHODS (LJ3) & .830 & .011 & .017 & -.011 & -.008 & .045 & .006 \\
\hline PROFESSORS' EXPERTISE (LJ4) & .484 & .034 & -.073 & -.425 & -.100 & .010 & -.016 \\
\hline EDUCATIONAL SERVICE (LJ5) & .471 & .044 & .096 & -.244 & -.201 & .080 & -.149 \\
\hline FACULTY INTERIOR (A1) & -.044 & .874 & .060 & -.020 & -.082 & -.028 & -.064 \\
\hline EXTERIOR OF THE FACULTY BUILDING (A2) & .053 & .824 & -.092 & .008 & .046 & -.027 & .071 \\
\hline IMPRESSION DURING THE STAY (A3) & .119 & .688 & .143 & -.049 & -.139 & .017 & -.087 \\
\hline FACULTY PROMOTION (P1) & .051 & -.092 & .790 & .036 & .165 & -.001 & -.092 \\
\hline MEDIA CAMPAIGN (P2) & -.094 & .129 & .662 & -.111 & -.165 & -.112 & -.028 \\
\hline FACULTY FLYERS (P3) & .003 & .086 & .643 & -.086 & .060 & -.010 & .066 \\
\hline STATE-FOUNDED FACULTY (I1) & .110 & -.010 & .008 & -.703 & .117 & .056 & -.040 \\
\hline FACULTY IMAGE (I2) & -.002 & .131 & .134 & -.677 & -.207 & .011 & -.020 \\
\hline FACULTY TRADITION (I3) & .092 & .324 & .113 & -.425 & .012 & .012 & .165 \\
\hline FACULTY WEBSITE (I4) & .057 & -.145 & .183 & -.346 & -.210 & .023 & .141 \\
\hline LIBRARY SERVICE (U1) & .013 & .059 & -.226 & -.043 & -.801 & -.085 & -.044 \\
\hline QUALITY OF LIBRARY FACILITIES (U2) & .096 & .051 & .028 & .162 & -.742 & .099 & .011 \\
\hline STUDENT AFFAIRS OFFICE'S SERVICE ( U3) & .035 & -.061 & .005 & -.123 & -.696 & -.066 & -.014 \\
\hline COMPUTER CLASSROOMS (U4) & .088 & .232 & .229 & .063 & -.367 & .140 & .053 \\
\hline MODERN TECHNOLOGY (U5) & .205 & .228 & .310 & .065 & -.332 & .078 & -.014 \\
\hline SECOND BRANCH (M1) & -.010 & -.050 & -.006 & -.262 & -.025 & .752 & .082 \\
\hline CITY - FACULTY LOCATION (M2) & -.052 & -.084 & .114 & -.052 & -.086 & -.747 & .293 \\
\hline DISTANCE LEARNING (M3) & -.124 & -.100 & .052 & .239 & -.096 & .420 & .315 \\
\hline DELAYED PAYMENT (C1) & -.026 & .038 & -.180 & -.232 & .006 & -.062 & .761 \\
\hline TUITION COSTS (C2) & .153 & -.019 & .177 & .278 & .004 & -.035 & .572 \\
\hline FACULTY BRANCH (C3) & -.100 & .316 & .022 & .047 & .185 & .149 & .334 \\
\hline Eigenvalues & 6.051 & 2.258 & 1.467 & 1.403 & 1.292 & 1.241 & 1.157 \\
\hline$\%$ of CommonVariance & 23.273 & 8.684 & 5.643 & 5.398 & 4.970 & 4.773 & 4.450 \\
\hline$\%$ of Cummulative Variance & 23.273 & 31.957 & 37.599 & 42.997 & 47.967 & 52.740 & 57.190 \\
\hline
\end{tabular}

Source: Authors' calculations 


\section{Dr Vesna Rodić Lukić}

Univerzitet u Novom Sadu, Pedagoški fakultet u Somboru

Nemanja Lukić, MSc

Univerzitet u Novom Sadu, Pedagoški fakultet u Somboru

\section{PRIMENA MARKETING MIKSA KONCEPTA KOD STRATEGIJE REGRUTOVANJA STUDENATA: UNIVERZITET U NOVOM SADU, SRBIJA}

Prvi predmet istraživanja u ovom radu je pregled i poređenje različitih teorijskih pristupa primeni marketinga u visokoobrazovnim institucijama. Autori posmatraju marketing kao aktivan proces u kojem visokoobrazovne institucije privlače pažnju svojih korisnika na obrazovne usluge koje nude. Istraživanjem se tražio odgovor na pitanje koji instrument marketing miksa ima najveći uticaj na odluku o upisu na odredeni fakultet na Univerzitetu u Novom Sadu. Istraživanje je obuhvatilo 783 studenta sa šest fakulteta ovog univerziteta. Autori su koristili nestandardizirani anketni upitnik za merenje stavova prema 26 različitih marketinških alata, uz pomoć Likertove lestvice od pet tačaka. Faktorska analiza sa primenom ekstrakcije faktora po metodu glavnih komponenti je korišćena za klasifikaciju varijabli. Autori izdvajaju sedam faktora koji su relevantni za izbor fakulteta: ljudi, fizički dokaz, promocija, imidž, resursi i dodatne usluge, mesto $i$ cena. Dobijeni rezultati se podudaraju sa tradicionalnim elementima marketing miksa (7P) u manjoj ili većoj meri, potvrđujući rezultate prethodno sprovedenih istraživanja.

Ključne reči: marketing mix, univerziteti, privlačenje studenata, menadžment fakulteta. 